\title{
Geostrophic transport in the Brazil Current region north of $20^{\circ} \mathrm{S}$
}

\author{
Lothar Stramma, ${ }^{*}$ Yoshimine Ikeda $\dagger$ and Ray G. Peterson*
}

(Received 1 December 1989; in revised form 27 June 1990; accepted 31 July 1990)

\begin{abstract}
Geostrophic volume transports in the upper $500 \mathrm{~m}$ are computed from historical hydrographic data for the area off the Brazilian coast west of $30^{\circ} \mathrm{W}$ and between $7^{\circ}$ and $20^{\circ} \mathrm{S}$. On the basis of water mass distributions, potential density surfaces of $\sigma_{\theta}=27.05 \mathrm{~kg} \mathrm{~m}^{-3}(360-670 \mathrm{~m})$ and $\sigma_{\theta}=27.6 \mathrm{~kg} \mathrm{~m}^{-3}(\sim 1200 \mathrm{~m})$ are used for referencing the meridional and zonal components of the geostrophic shears, respectively. Near $15^{\circ} \mathrm{S}$ a northwestward flow of $8 \mathrm{~Sv}$ crosses $30^{\circ} \mathrm{W}$. This current reaches the shelf near $10^{\circ} \mathrm{S}$ in February and March, the only two months for which observations are available near that latitude along the coast; of the $8 \mathrm{~Sv}$, about $4 \mathrm{~Sv}$ continue towards the northwest into the North Brazil Current while another branch also carrying 4 Sv turns southward as the beginning of the Brazil Current. Between $10^{\circ}$ and $20^{\circ} \mathrm{S}$ the Brazil Current does not appear to strengthen appreciably, but because of the likely existence of flow on the shelf these transport values represent lower limits to the actual ones. At $30^{\circ} \mathrm{W}$, another westward flow of approximately 8-10 Sv enters the area near $10^{\circ} \mathrm{S}$ and serves to strengthen the North Brazil Current. The total transfer of $12 \mathrm{~Sv}$ or more from the South Equatorial Current into the North Brazil Current and later to other currents and the northern hemisphere may be an important factor contributing to the well-known weakness of the Brazil Current in its more northerly latitudes.
\end{abstract}

\section{INTRODUCTION}

THE Brazil Current has its origins with the southernmost part of the South Equatorial Current, but just where the southward geostrophic flow along the coast actually begins is not especially clear. Ship drift data have long shown the Brazil Current to originate with the bifurcation of the South Equatorial Current near Cabo de São Roque $\left(5^{\circ} 30^{\prime}\right.$ S) (RENNELL, 1832), a feature that also can be seen in the trajectories of satellite-tracked drifting buoys (Molinari, 1983; Reverdin and McPhaden, 1986). However, the initial southward drift near Cabo de São Roque is probably realized only in the Ekman layer which has the same southward motion (RICHARDSON and WALSH, 1986; ARNAULt, 1987); there seem to be no southward geostrophic surface currents north of $10^{\circ} \mathrm{S}$ (ARNAULT, 1987). This might be expected considering that the main westward current of the South Atlantic subtropical gyre remains south of $10^{\circ} \mathrm{S}$ except near the coast of Brazil (TsuchiYA, 1986).

The transport of the Brazil Current is generally considered to be small when compared with that of the Gulf Stream, its western boundary counterpart in the North Atlantic. As summarized by Peterson and Stramma (1990), the Brazil Current has been reported to transport only about $5 \mathrm{~Sv}\left(1 \mathrm{~Sv}=10^{6} \mathrm{~m}^{3} \mathrm{~s}^{-1}\right)$ of surface water near $20^{\circ} \mathrm{S}$. At about $20.5^{\circ} \mathrm{S}$

\footnotetext{
*Institut für Meereskunde an der Universität Kiel, Düsternbrooker Weg 20, 2300 Kiel, F.R.G.
}

†Instituto Oceanográfico, Universidade de Sāo Paulo, 05508 São Paulo SP, Brazil. 
the Brazil Current encounters a zonal seamount chain, the Vitoria-Trindade Ridge. EvaNs et al. (1983) observed the current to flow through the inshore-most passage and not through passages farther to the east. North of the seamount chain, at $19^{\circ} \mathrm{S}$, they obtained a transport of $5.3 \mathrm{~Sv}$ relative to $500 \mathrm{~m}$ in April 1982, which is slightly less than the $6.5 \mathrm{~Sv}$ relative to an isanosteric surface near $500 \mathrm{~m}$ depth computed by MiRANDA and CASTRO FIL Ho (1982) for September 1967. The greatest surface speed observed in April 1982 was $50 \mathrm{~cm} \mathrm{~s}^{-1}$, and in September 1967 it was $72 \mathrm{~cm} \mathrm{~s}^{-1}$.

From data obtained during the Brazilian participation in the International Geophysical Year (IGY) 1957/58, Silva (1957) found three anticyclonic cells of recirculation in the dynamic height field relative to $500 \mathrm{dbar}$; they were located near Cabo São Tomé $\left(22^{\circ} \mathrm{S}\right)$, Ilha da Trindade $\left(21^{\circ} \mathrm{S}\right)$ and north of Banco da Vitória $\left(18^{\circ} \mathrm{S}\right)$. LuEDEMANN (1975) released drift bottles off the east coast of Brazil at $18^{\circ} 30^{\prime} \mathrm{S}$ to $20^{\circ} \mathrm{S}$ in July 1972 , with the locations of the recovered bottles suggesting the existence of two branches of the Brazil Current flowing south. The coastal branch was traced between $18^{\circ} 30^{\prime} \mathrm{S}$ and $21^{\circ} 30^{\prime} \mathrm{S}$ and had a relatively high velocity on the order of $50 \mathrm{~cm} \mathrm{~s}^{-1}$. The offshore branch had a lower velocity of $13 \mathrm{~cm} \mathrm{~s}^{-1}$ and might have been influenced by eddies and meanders. MAGLIocCA (1978) studied the oxygen minimum layer near the Brazilian coast between $7^{\circ}$ and $22^{\circ} \mathrm{S}$, finding the core of the layer to be located in the isopycnal range of $\sigma_{t}=26.8-27.2 \mathrm{~kg} \mathrm{~m}^{-3}$, which lies at depths of $300-400 \mathrm{~m}$ at $7^{\circ} \mathrm{S}$ and $600-800 \mathrm{~m}$ at $22^{\circ} \mathrm{S}$. This oxygen minimum represents the lower limits of the southward-flowing Brazil Current water just above the Antarctic Intermediate Water (AAIW) moving north.

It is still unclear how much water is transported by the Brazil Current in the region north of $20^{\circ} \mathrm{S}$, as well as where the southward geostrophic flow along the coast first appears. There are no estimates of the Brazil Current transport in the general literature for latitudes north of $19^{\circ} \mathrm{S}$. In this paper we compute geostrophic transports from historical hydrographic data for the Brazil Current north of $20^{\circ} \mathrm{S}$; the transport south of $23^{\circ} \mathrm{S}$ was the subject of an earlier paper (Stramma, 1989). In addition to the new transport values obtained here, we also identify the area where the South Equatorial Current bifurcates into the Brazil Current and North Brazil Current (the latter often being called the North Brazilian Coastal Current) during the austral summer.

\section{DATA AND METHODS}

Except for two Meteor sections (Table 1), all data used here are archived at the World Oceanographic Data Centre A (WODC, status 1988). Extracted from the WODC data set are 14 hydrographic sections which start near the Brazilian shelf between $7^{\circ}$ and $20^{\circ} \mathrm{S}$ and extend generally eastward. All but four of these sections reach the vicinity of $30^{\circ} \mathrm{W}$ (Fig. 1). In addition to the zonal sections, six meridional sections along $30^{\circ} \mathrm{W}$ are extracted from the historical data set which serve to close our region on the eastern side. For clarity only two of these six sections, one made from the Hudson in December 1969 and another from the Prof. Vize in April 1969, are included in Fig. 1. Two other sections were made by the Lomonosov in May 1959 and June 1961, while another came from the $A k$. Shirshov in April 1970; the remaining section came from the Oceanus in February 1983. CTD data were taken only on the Oceanus section, whereas all the other stations consist of bottle data.

A quality check has been performed on all the station data and obviously incorrect values have been removed on the basis of $T-S$ diagrams. The scatter in these diagrams is 


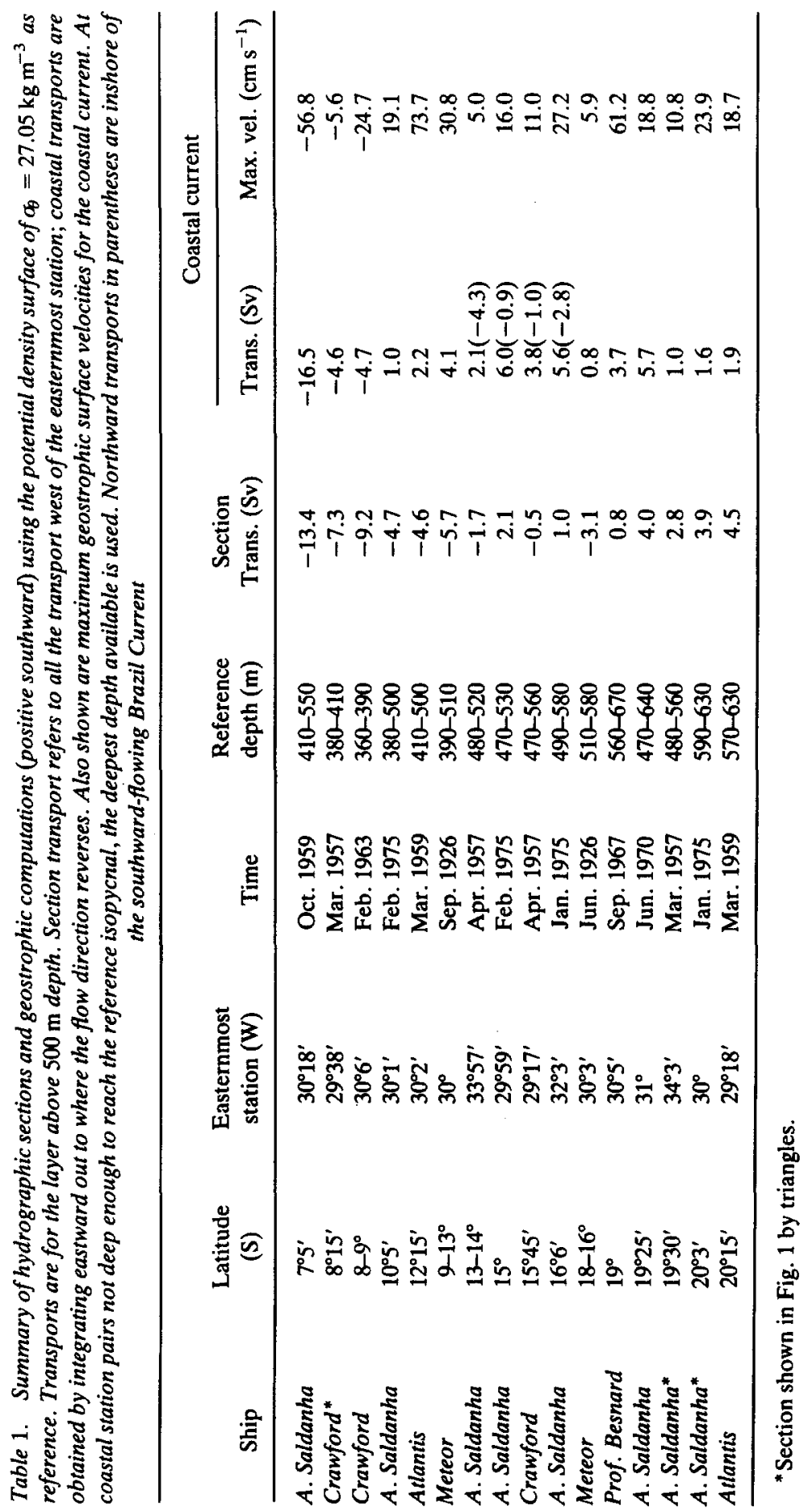




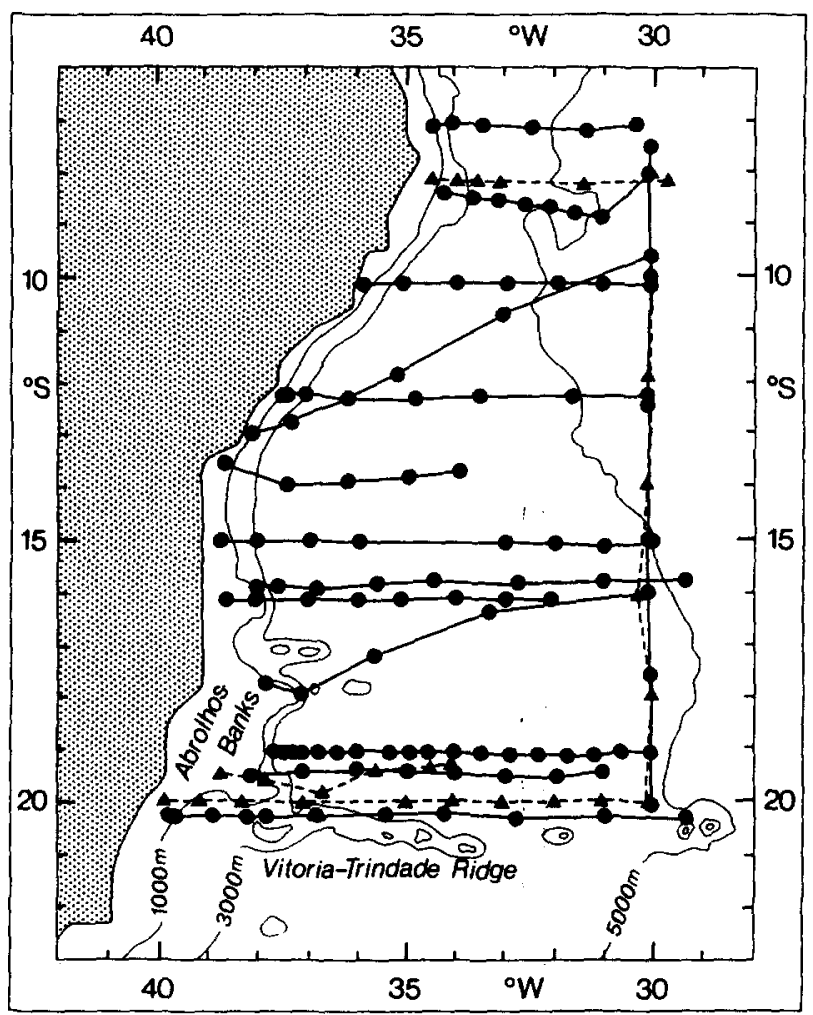

Fig. 1. Positions of hydrographic stations along all the zonal sections used here (Table 1) and two of the six meridional sections described in the text (dots: Hudson, December 1969; triangles: Prof. Vize, April 1969), together with bottom bathymetry. Dashed lines and triangles on selected zonal sections are used only for clarity.

small in the IGY data (Crawford, Atlantis) and in the Oceanus CTD section, but other sections contain considerably more scatter. The most noise appears in the sections from the Ak. Shirshov, the Prof. Vize, and in the older sections from the A. Saldanha. Nevertheless, these sections still appear to be useful for making geostrophic computations as they yield similar flow fields and transports as do the sections with small scatter.

Assuming the flow to be primarily along isopycnal surfaces, we use vertical distributions of water mass properties to find a potential density surface where the motion might vanish and thereby provide a suitable reference for adjusting geostrophic velocity profiles. These properties have been described by REID et al. (1977) for the western South Atlantic south of about $20^{\circ} \mathrm{S}$ and have been summarized on a north-south section by PETERSON and WHITWORTH (1989). In our region, the uppermost warm and salty water mass is the Tropical Water that lies above the South Atlantic Central Water (SACW), whose lower limits are indicated by an oxygen minimum near $500 \mathrm{~m}$ depth. Directly underneath is the AAIW, which is identified by an oxygen maximum just above a salinity minimum at depths of approximately $700-800 \mathrm{~m}$. The upper branch of Circumpolar Deep Water (CDW) is the next deepest water mass, and is characterized by minima in both temperature and oxygen near $1000-1200 \mathrm{~m}$. The final water mass of concern to us is the upper branch of North 
Atlantic Deep Water (NADW), it being characterized by a weak temperature maximum overlying maxima in salinity and oxygen.

The directions of motion in these layers in the southwestern South Atlantic (away from the western boundary) do not appear to change significantly with depth. Defant (1941, plate XXVI) showed the 800 dbar velocity field as reflecting the gyre circulation. BusCAGLIA (1971) explicitly observed the AAIW as circulating in the same direction as the surface water, a finding in agreement with REID et al. (1977), who presented additional evidence that the anticyclonic motion extends downward through the NADW. In the tropical South Atlantic there is another circulation regime, a cyclonic gyre, roughly triangular in shape, having greatest latitudinal extent near the African shelf and narrowing toward the west (REID, 1989). The transition between the subtropical anticyclonic and tropical cyclonic gyres is oriented along the zero-line in the annual mean field of wind stress curl over the South Atlantic (Gordon and Bosley, 1990; Peterson and Stramma, 1990). In the east, the tropical cyclonic gyre extends to great depth (KIRWAN, 1963; REID, 1989), but the vertical coherence of direction is less apparent in the west where its northern limb approaches the eastern promontory of Brazil (REID, 1989). Finally, at the western boundary at low latitudes, there are sharp changes in the direction of flow between various layers. Using a Pegasus profiler to obtain absolute velocities in the Brazil Current near $23^{\circ} \mathrm{S}$, Evans and SignORINI (1985) found the flow to be southward in the upper $400 \mathrm{~m}$, but toward the north in the underlying AAIW. There is another reversal at depth due to the NADW flowing south along the shelf as a western boundary current (DEFANT, 1941).

The AAIW is known to flow northward along the South American continental shelf, and its presence can be seen in the vertical section of oxygen on an east-west line along $15^{\circ} 45^{\prime} \mathrm{S}$ (Fig. 2). The highest values in this layer exceed $4.4 \mathrm{mll}^{-1}$ west of $35^{\circ} \mathrm{W}$, and gradually erode toward the east. Above the high-oxygen core of AAIW near the shelf is the minimum associated with the lower reaches of SACW. Between these two extrema in the west is the potential isopycnal of $\sigma_{\theta}=27.05 \mathrm{~kg} \mathrm{~m}^{-3}$, which we choose as a reference

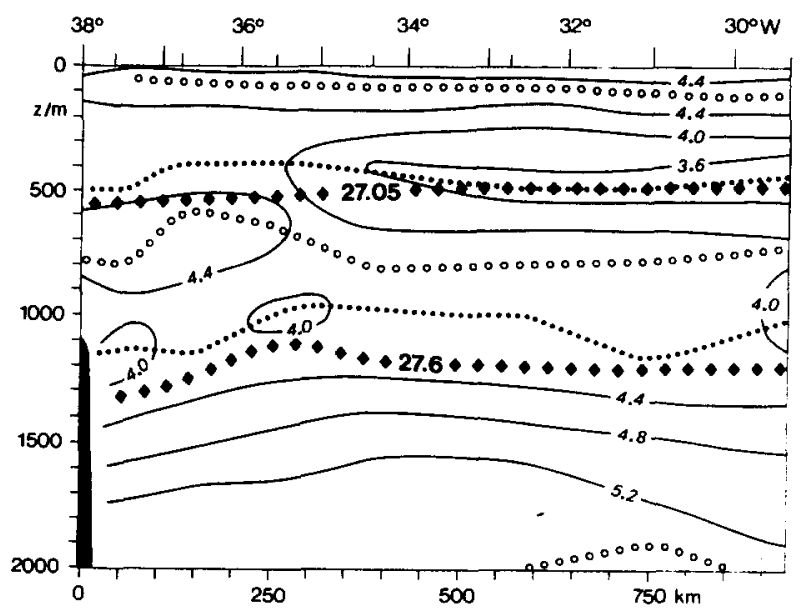

Fig. 2. Vertical distribution of oxygen $\left(\mathrm{ml} \mathrm{l}^{-1}\right)$ in the upper $2000 \mathrm{~m}$ along the west (left)-east (right) line of stations occupied by Crawford at $15^{\circ} 45^{\prime} \mathrm{S}$ in April 1957. Relative minima are denoted by dots and maxima by open circles. Also shown are the isopycnals of $\sigma_{\theta}=27.05$ and $27.6 \mathrm{~kg} \mathrm{~m}^{-3}$ (diamonds). 


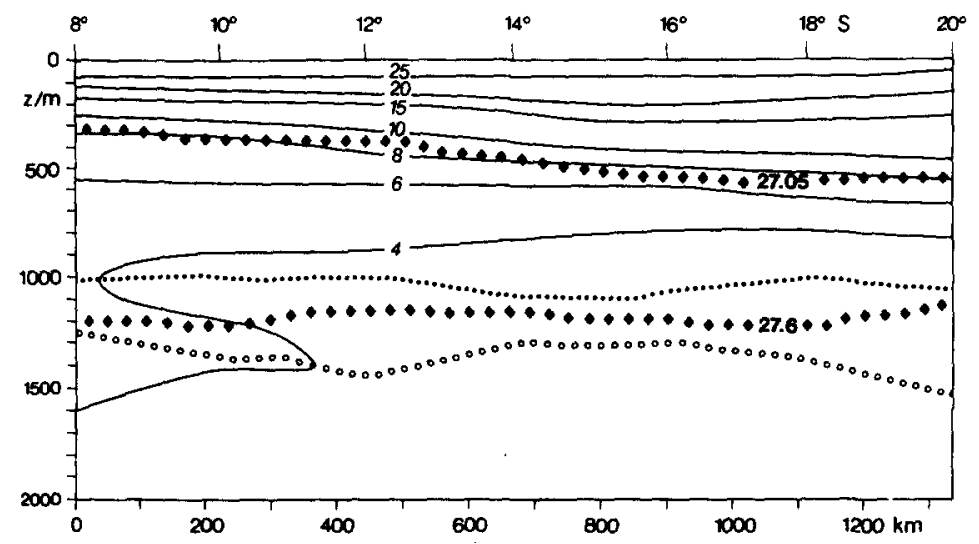

Fig. 3. Vertical distribution of temperature in ${ }^{\circ} \mathrm{C}$ in the upper $2000 \mathrm{~m}$ along the north (left)-south (right) line of stations occupied by Prof. Vize at $30^{\circ} \mathrm{W}$ in April 1969. Relative minima are denoted by dots and maxima by open circles. Also shown are the isopycnals of $\sigma_{\theta}=27.05$ and $27.6 \mathrm{~kg} \mathrm{~m}^{-3}$

(diamonds).

for computing the geostrophic transport of the Brazil Current, similar to what was done by Stramma and Peterson (1989) in the Benguela Current region.

The optimal zero-reference for the zonal flow component in regions away from the western boundary in the tropical South Atlantic lies at greater depth than the boundary between SACW and AAIW, and is less easily identified. According to REID (1989) the SACW and AAIW have the same flow direction at about $30^{\circ} \mathrm{W}$. As shown in Fig. 1, we have closed our region to the east with north-south lines of hydrographic stations along $30^{\circ} \mathrm{W}$. A vertical section of temperature along that meridian is shown in Fig. 3. Although this field has little structure other than the thermocline stratification, a weak minimum associated with the upper branch of CDW and a maximum due to NADW are present and separated in depth by only $200-300 \mathrm{~m}$, providing perhaps the best indication of where the boundary between these two water masses is. As shown in Fig. 3, the potential density surface of $\sigma_{\theta}=27.6 \mathrm{~kg} \mathrm{~m}^{-3}$ lies between the two extrema, and is used along this section as reference for geostrophic computations.

A mismatch exists between the reference used for the zonal sections and that used for the meridional section, which naturally leads to mass imbalances. These are discussed in the following section. However, our primary objectives, i.e. to determine the spatial patterns of flow in the southern South Equatorial Current as it nears the western boundary and to provide estimates for the volume transport of the newly formed Brazil Current, are met by using this method.

\section{OBSERVATIONS}

The geostrophic transports across the zonal sections, computed relative to the potential density $\sigma_{\theta}=27.05 \mathrm{~kg} \mathrm{~m}^{-3}$ for the upper $500 \mathrm{~m}$ (Table 1), show a northward-directed geostrophic flow along the coast at latitudes north of $9^{\circ} \mathrm{S}$, flow which is part of the North Brazil Current. We have only three sections within this current, and its largest transport, more than $16 \mathrm{~Sv}$, is observed at $7^{\circ} \mathrm{S}$ in the month of October. This is nearly $12 \mathrm{~Sv}$ more than obtained just a degree farther south during the opposite time of year, which may at first be 
suggestive of a strong seasonal signal. But from maps in the paper by Cochrane et al. (1979), it appears as though the North Brazil Current is stronger in February-April and weaker in July-September. As discussed below, the rapid intensification we observe is likely brought about by the merging of two branches of the South Equatorial Current.

The southward geostrophic flow of the Brazil Current first appears at about $10^{\circ} \mathrm{S}$, and just two degrees farther south the surface speeds can exceed $70 \mathrm{~cm} \mathrm{~s}^{-1}$. Unfortunately, because our four sections between $8^{\circ} 15^{\prime} \mathrm{S}$ and $12^{\circ} 15^{\prime} \mathrm{S}$ were all made in February and March it is not possible for us to speculate on any possible seasonality in the formation latitude of the Brazil Current. Between $10^{\circ}$ and $20^{\circ} \mathrm{S}$ the (coastal) Brazil Current is found to transport on the order of 1-6 Sv, and the variations are not systematic with respect to time of year. Because these transport values are so small, any seasonality could be obscured by data noise and by the Brazil Current in its northern reaches being a shallow feature, often residing up on the continental shelf (reviewed by PETERSON and STramma, 1990). However, a systematic pattern does seem to exist in the flow field itself. In all sections south of $10^{\circ} \mathrm{S}$ a northward flow is observed to the east of the coastal flow with a second southward flow farther offshore (but still west of $30^{\circ} \mathrm{W}$ ). The total transport in the upper $500 \mathrm{~m}$ west of $30^{\circ} \mathrm{W}$ is directed poleward south of $15^{\circ} \mathrm{S}$ and equatorward north of there.

The velocity distribution along the $A$. Saldanha section at $15^{\circ} \mathrm{S}$ in February 1975 (Fig. 4) shows two southward current bands, the coastal one having a maximum surface speed of

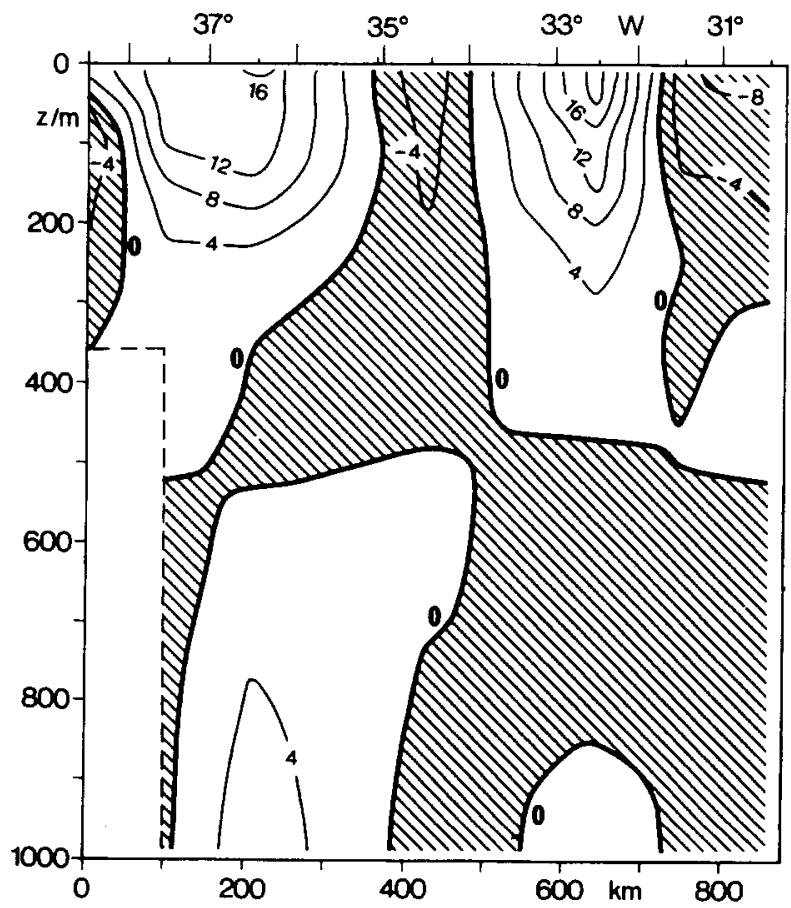

Fig. 4. Vertical distribution of geostrophic velocity $\left(\mathrm{cm} \mathrm{s}^{-1}\right)$ relative to the isopycnal $\sigma_{\theta}=27.05 \mathrm{~kg} \mathrm{~m}^{-3}$ for the $A$. Saldanha section at $15^{\circ} \mathrm{S}$ in February 1975 . Positive velocity is southward, negative velocity is directed northward and indicated by shading. Short tick-marks on top show the mid-points between stations. The broken line on the left side indicates where no velocity estimates exist due to shallow bathymetry. 


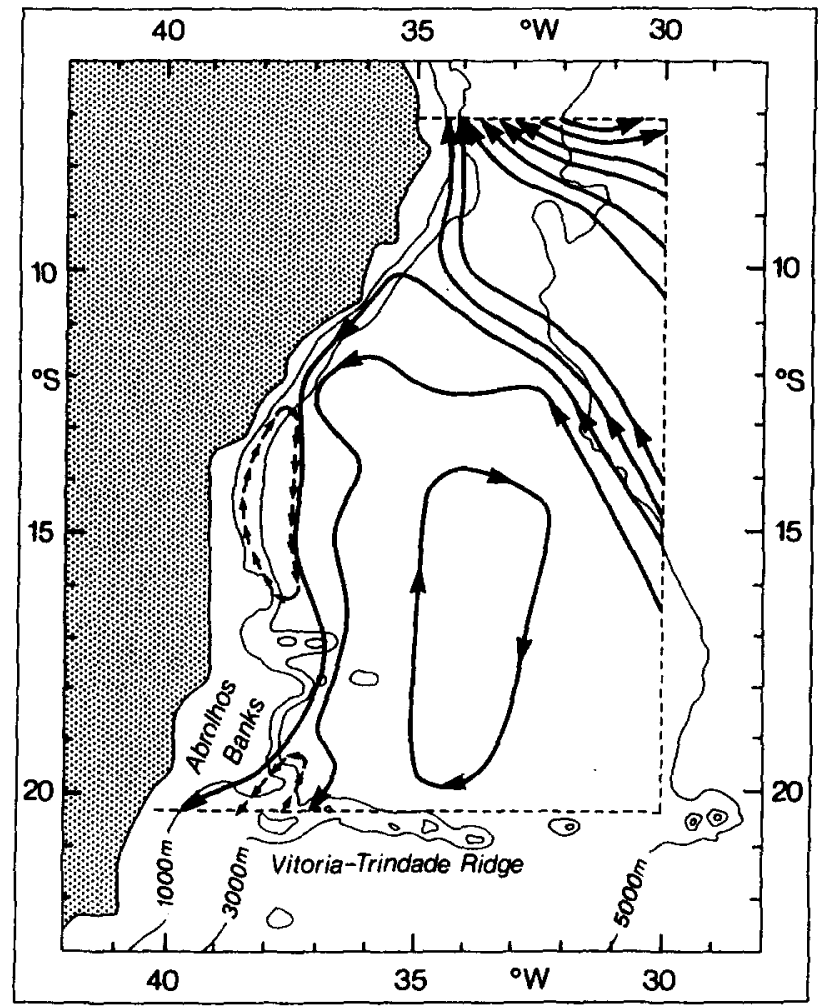

Fig. 5. Schematic representation of the geostrophic flow field in the upper $500 \mathrm{~m}$ based on historical hydrographic data within the region defined by the dashed box. Solid flow lines represent a transport of $2 \mathrm{~Sv}$, disconnected arrows a transport of $1 \mathrm{~Sv}$. The location of where the South Equatorial Current bifurcates is based on data obtained in the months of February and March.

$16 \mathrm{~cm} \mathrm{~s}^{-1}$ and another farther offshore with $20 \mathrm{~cm} \mathrm{~s}^{-1}$. Both of these bands are surface features where speeds of $8 \mathrm{~cm} \mathrm{~s}^{-1}$ or more are restricted to the upper $200 \mathrm{~m}$. A similar two-banded structure in the surface layer is also present in the other sections south of $10^{\circ} \mathrm{S}$.

A schematic representation of the geostrophic flow field based on our data is constructed to fit the major features observed (Fig. 5). However, because of the mass imbalances resulting from the use of non-synoptic sections and a deeper reference layer along $30^{\circ} \mathrm{W}$ than along the zonal sections, this field does not closely fit all the transport estimates in Table 1. Most important, though, is that this field shows the essential qualities of the flow. The geostrophic flow of the Brazil Current begins at about $10^{\circ} \mathrm{S}$ and separates from the coast near $12^{\circ} \mathrm{S}$. As noted above, this formation latitude for the Brazil Current is based only on data taken during the months of February and March. Between $12^{\circ}$ and $16^{\circ} \mathrm{S}$ there is a weak cyclonic circulation inshore of the Brazil Current, with the northward flow along the shelf carrying an average of only about $2 \mathrm{~Sv}$. There appears to be another (and larger) cyclonic gyre offshore of the Brazil Current centered near $17^{\circ} \mathrm{S}, 34^{\circ} \mathrm{W}$. The manner in which it is contoured here is only one possible interpretation. Another would be a southward meandering of the southernmost part of the South Equatorial Current and a subsequent northward reflection at the Vitoria-Trindade Ridge. The transport of the 
Brazil Current itself, roughly $4 \mathrm{~Sv}$, agrees with observations made in the region of the Vitoria-Trindade Ridge during April 1982 by Evans et al. (1983). They estimated a geostrophic transport relative to $500 \mathrm{~m}$ of $5.3 \mathrm{~Sv}$ at $19^{\circ} \mathrm{S}, 3.8 \mathrm{~Sv}$ at $20^{\circ} 28^{\prime} \mathrm{S}$, and $4.4 \mathrm{~Sv}$ at $21^{\circ} 40^{\prime} \mathrm{S}$.

From the six sections along $30^{\circ} \mathrm{W}$, no westward current band can be distinctly identified as being a stable feature in all the sections. Instead, the flow is spread broadly with many irregularities (including occasional countercurrents) over most of the section. Typical for the sections at $30^{\circ} \mathrm{W}$, however, is a somewhat stronger westward branch at $8^{\circ}-11^{\circ} \mathrm{S}$ and another near $15^{\circ} \mathrm{S}$, which are included in Fig. 5. Except for an Oceanus section (which starts at only $11^{\circ} 50^{\prime} \mathrm{S}$ ) the westward geostrophic transports in the upper $500 \mathrm{~m}$ across these meridional sections between $8^{\circ}$ and $20^{\circ} \mathrm{S}$ relative to the potential density surface of $\sigma_{\theta}=27.6 \mathrm{~kg} \mathrm{~m}^{-3}$ varies from 18 to $25 \mathrm{~Sv}$. For the Oceanus section, there is a total westward transport of $13.3 \mathrm{~Sv}$ between $11^{\circ} 50^{\prime} \mathrm{S}$ and $20^{\circ} 8^{\prime} \mathrm{S}$. The westward transport of $16 \mathrm{~Sv}$ shown in Fig. 5 is smaller than the 18-25 Sv across the other sections because of the deeper reference level used along the meridional sections $\left(\sigma_{\theta}=27.6 \mathrm{~kg} \mathrm{~m}^{-3}\right)$ than in the zonal sections $\left(\sigma_{\theta}=27.05 \mathrm{~kg} \mathrm{~m}^{-3}\right)$. If the shallower reference is used along $30^{\circ} \mathrm{W}$, the westward transport averages about $13 \mathrm{~Sv}$, suggesting that the actual value might be near that contoured in Fig. 5.

Also evident from Fig. 5 is that most of the transport of the two quasi-permanent branches of the South Equatorial Current continue equatorward across $10^{\circ} \mathrm{S}$ into the North Brazil Current. The beginnings of this current as a near-coastal geostrophic feature appear to be with the southern portions of the South Equatorial Current near $10^{\circ} \mathrm{S}$ with a transport of about $4 \mathrm{~Sv}$, but with the input of the other branch of the South Equatorial Current, the North Brazil Current strengthens to more than $16 \mathrm{~Sv}$ at $7^{\circ} \mathrm{S}$ (Table 1 ). However, it should be noted that these estimates of the North Brazil current transport are likely to be lower than the actual values because the underlying AAIW is probably moving in the same direction, and we have not adjusted our reference level accordingly. Also not well resolved in the northeastern corner of our region is the eastward-flowing South Equatorial Countercurrent, which MolinARI (1982) observed as being located between $7^{\circ}$ and $9^{\circ} \mathrm{S}$ at $25^{\circ}-28^{\circ} \mathrm{W}$.

Referring again to Fig. 5, the continental shelf is relatively narrow north of about $15^{\circ} \mathrm{S}$. Because of this, and because of the small cyclonic circulation near the coast, it is doubtful that very much of the Brazil Current escaped measurement in this region. However, for regions south of $15^{\circ} \mathrm{S}$ it is likely that we have underestimated the transport of the Brazil Current. The WODC data we have used came only from stations which are at least $200 \mathrm{~m}$ deep. At $23^{\circ} \mathrm{S}$, Evans and Signorini (1985) found that part of the Brazil Current exists inshore of the $200-\mathrm{m}$ isobath, with the inshore transport amounting to about $5 \mathrm{~Sv}$. Such a flow is also possible on the broad shelf at the Abrolhos Banks between $16^{\circ}$ and $20^{\circ} \mathrm{S}$, which we are not able to resolve.

That we have probably underestimated the Brazil Current transport near the Abrolhos Banks is attested to by the results obtained by Miranda and Castro Filho (1982). They used the same section made from the Prof. Besnard at $19^{\circ} \mathrm{S}$ as we have, but they had two additional station pairs on the shelf with which to work. They estimated the net flux of the Brazil Current as being $6.5 \mathrm{~Sv}$, whereas we find only $3.7 \mathrm{~Sv}$. But part of the difference is also due to using different reference depths. They used the $130 \mathrm{cl}^{-1}{ }^{-1}$ isanosteric surface (near $520 \mathrm{~m}$ depth) versus our reference of $\sigma_{\theta}=27.05 \mathrm{~kg} \mathrm{~m}^{-3}$ (at about $670 \mathrm{~m}$ depth beneath the Brazil Current). Using a fixed reference depth of $520 \mathrm{~m}$, we obtain a transport 
of 5.0 Sv for the coastal Brazil Current. In their conclusions, Miranda and Castro Filho (1982) stated that the Brazil Current near the continental slope transports about $5.5 \mathrm{~Sv}$, which is similar to our $5.0 \mathrm{~Sv}$ using a reference of $520 \mathrm{~m}$. The $1 \mathrm{~Sv}$ difference between their two values of 5.5 and $6.5 \mathrm{~Sv}$ might be their estimate of the shelf transport, but they were not explicit about this.

A large difference also exists between our transport of $0.8 \mathrm{~Sv}$ for the Brazil Current across the Meteor section at $18^{\circ}-16^{\circ} \mathrm{S}$ and a transport of $6.2 \mathrm{~Sv}$ in the upper $600 \mathrm{~m}$ which can be extracted from Table IX in Wüst (1957). The reasons for the difference are again because of reference depth (Wüst used $1000-1200 \mathrm{~m}$ ), and because Wüst extrapolated Meteor Sta. 161, which was made on the shelf in only $60 \mathrm{~m}$ depth, down to $1200 \mathrm{~m}$, whereas we have made no such extrapolation.

Because the station spacing in our sections is not uniform, and often quite large (Fig. 1), the large scatter in our coastal current velocities (Table 1) is not surprising. However, the highest velocity, nearly $75 \mathrm{~cm} \mathrm{~s}^{-1}$, comes from an unexpectedly far north latitude of $12^{\circ} 15^{\prime} \mathrm{S}$. This leads to the question as to whether or not there might be southward geostrophic flow on the shelf north of $10^{\circ} \mathrm{S}$, where we have found the bifurcation of the South Equatorial Current (in February-March). Because all our data come from stations in water depths of $200 \mathrm{~m}$ and more, we are unable to provide an answer. There also might be some seasonality or interannual variability involved, which we are again unable to adequately resolve. DEFANT (1941, plate XXII), showed a coastal flow towards the south beginning near $5^{\circ} \mathrm{S}$, but his field was likely based on ship drifts in this region: his 100-dbar velocity field (DEFANT 1941, Fig. 51) has a poleward component along the coast only from $11^{\circ} \mathrm{S}$ and southward.

\section{DISCUSSION}

As it has long been known, the newly formed Brazil Current is very weak as far as western boundary currents go. Part of the reason might be surmised by the patterns shown in Fig. 5. Although we are not sampling the entire South Equatorial Current as it reaches the vicinity of the western boundary, it seems clear that most of its water is transported into the North Brazil Current, after which it would be lost to other currents and the northern hemisphere (helping to intensify the Gulf Stream). Only about $4 \mathrm{~Sv}$ get into the Brazil Current. Farther upstream in the circulation of the subtropical gyre, the Benguela Current supplies more than 20 Sv to the South Equatorial Current (STramma and PeTERSon, 1989), of which less than $10 \mathrm{~Sv}$ is thermocline water from the Indian Ocean (GoRDon et al. 1987; Stramma and Peterson, 1990). On our northernmost zonal section, made by the $A$. Saldanha near $7^{\circ} \mathrm{S}$, we obtain a transport for the North Brazil Current of $16.5 \mathrm{~Sv}$ (Table 1), roughly twice that which comes from the Indian Ocean into the southern Benguela Current. Our other zonal sections lie farther south and sample less or none of the North Brazil Current. As pointed out by Gordon and Bosley (1990) and PeTERSon and Stramma (1990), the zero-line of the annual mean curl of wind stress in the lower latitudes of the South Atlantic is oriented diagonally across the basin from near Cape Town to equatorial latitudes north of the northern coast of Brazil. It does not intersect the South American coast south of the equator, in which case one might expect from Sverdrup dynamics that the subtropical gyre does not completely recirculate, thus leading to a loss of water from the gyre to the North Brazil Current. This loss of water appears to be real, and could be largely compensated by flux in the Ekman layer, which RoEммIсH (1983) estimated in the 
South Atlantic as being 13.7 Sv southward across $8^{\circ} \mathrm{S}$ (in the annual mean). But regardless of how the compensation takes place, the geostrophic transfer of subtropical gyre water into the North Brazil Current may be one of the mechanisms leading to the overall weakness of the early Brazil Current.

Here we have used the available historical data to map (for the first time we believe) the general geostrophic flow field in the surface layer near the Brazilian coast north of the Vitoria-Trindade Ridge. Although some of our data are not of the highest quality, the patterns we have obtained should be fairly accurate. Unfortunately, our data from the region near the coast where the southernmost portion of the South Equatorial Current splits into the Brazil and North Brazil currents come only from February and March, so we are unable to resolve any possible seasonality in the bifurcation. Many more high-quality measurements from all seasons, including shallow stations on the shelf, are needed for this.

Acknowledgements - This work has been supported by the Bundesminister für Forschung und Technologie grant 07K2128-12a (L.S.), the Deutsche Forschungsgemeinschaft grant Si 111/34-1 (R.G.P.), both at Bonn, F.R.G., and Banco Interamericano de Desenvolvimento (BID) as well as Universidade de São Paulo, Brazil (Y.I.).

\section{REFERENCES}

ARNAUlt S. (1987) Tropical Atlantic geostrophic currents and ship drifts. Journal of Geophysical Research, 92 , 5076-5088.

BusCAGLIA J. L. (1971) On the circulation of the Intermediate Water in the southwestern Atlantic Ocean. Journal of Marine Research, 29, 245-255.

Cochrane J. D., F. J. Kelly, Jr and C. R. Olling (1979) Subthermocline countercurrents in the western equatorial Atlantic Ocean. Journal of Physical Oceanography, 9, 724-738.

Defant A. (1941) Die absolute Topographie des physikalischen Meeresniveaus und der Druckflächen sowie die Wasserbewegungen im Raum des Atlantischen Ozeans. Wissenschaftliche Ergebnisse der deutschen Atlantischen Expedition Forschungs- und Vermessungsschiff Meteor 1925-1927, 6, Teil 2, 5. Lieferung, 191260.

Evans D. L. and S. S. Signorini (1985) Vertical structure of the Brazil Current. Nature, 315, 48-50.

Evans D. L., S. R. Signorin and L. B. Miranda (1983) A note on the transport of the Brazil Current. Journal of Physical Oceanography, 13, 1732-1738.

Gordon A. L. and K. T. BosLey (1990) Cyclonic gyre in the tropical South Atlantic. Deep-Sea Research, in press.

Gordon A. L., J. R. E. LutJeharms and M. L. Gründlingh (1987) Stratification and circulation at the Agulhas Retroflection. Deep-Sea Research, 34, 565-599.

KIRWAN A. D. (1963) Circulation of Antarctic Intermediate Water deduced through isentropic analysis. TAMU reference 63-34F, Texas A \& M University, College Station, 34 pp. , 35 plates.

Luedemann E. F. (1975) Contribuição ao estudo das correntes de superfície diante da costa leste brasileira $\left(18^{\circ} 30^{\prime} \mathrm{S}-20^{\circ} 00^{\prime} \mathrm{S}\right.$ até $\left.38^{\circ} 40^{\prime} \mathrm{W}\right)$. Boletim do Instituto Oceanografico São Paulo, 24, 69-84.

Magliocca A. (1978) O mínimo de oxigênio na costa leste do Brasil entre 7 a $22^{\circ} \mathrm{S}$. (The minimum oxygen concentration in eastern Brazilian coast between $7-22^{\circ} \mathrm{S}$ ). Boletim do Instituto Oceanografico São Paulo, 27, 79-94.

Miranda L. B. and B. M. CAstro Filho (1982) Geostrophic flow conditions of the Brazil Current at $19^{\circ}$ S. Ciencia Interamericana, 22, 44-48.

Molinarı R. L. (1982) Observations of eastward currents in the tropical South Atlantic Ocean: 1978-1980. Journal of Geophysical Research, 87, 9707-9714.

MOLINARI R. L. (1983) Observations of near-surface currents and temperature in the central and western tropical Atlantic Ocean. Journal of Geophysical Research, 88, 4433-4438.

Peterson R. G. and T. Whitworth III (1989) The subantarctic and polar fronts in relation to deep water masses through the southwestern Atlantic. Journal of Geophysical Research, 94, 10817-10838.

Peterson R. G. and L. Stramma (1990) Upper-level circulation in the South Atlantic Ocean. Progress in Oceanography, in press. 
Reid J. L. (1989) On the total geostrophic circulation of the South Atlantic Ocean: flow patterns, tracers and transports. Progress in Oceanography, 23, 149-244.

Reid J. L., W. D. Nowlin, Jr and W. C. Patzert (1977) On the characteristics and circulation of the southwestern Atlantic Ocean. Journal of Physical Oceanography, 7, 62-91.

RENNELL J. (1832) An investigation of the currents of the Atlantic Ocean, and of those which prevail between the Indian Ocean and the Atlantic, J. G. \& F. Rivington, London, 299 pp., 2 plates.

Reverdin G. and M. J. McPhADEN (1986) Near-surface current and temperature variability observed in the equatorial Atlantic from drifting buoys. Journal of Geophysical Research, 91, 6569-6581.

RichaRDSON P. L. and D. WALSH (1986) Mapping climatological seasonal variations of surface currents in the tropical Atlantic using ship drifts. Journal of Geophysical Research, 91, 10537-10550.

Rоеммісн D. (1983) The balance of geostrophic and Ekman transports in the tropical Atlantic Ocean. Journal of Physical Oceanography, 13, 1534-1539.

Silva P. C. M. (1957) Oceanografia do triângulo Cabo Frio-Trindade-Salvador. Anais Hydrografico Tomo, XVI, 213-308.

Stramma L. (1989) The Brazil Current transport south of $23^{\circ}$ S. Deep-Sea Research, 36, 639-646.

Stramma L. and R. G. Peterson (1989) Geostrophic transport in the Benguela Current region. Journal of Physical Oceanography, 19, 1440-1448.

Stramma L. and R. G. Peterson (1990) The South Atlantic Current. Journal of Physical Oceanography, 20, 846859.

TsuchiYA M. (1986) Thermostads and circulation in the upper layer of the Atlantic Ocean. Progress in Oceanography, 16, 235-267.

Wüst G. (1957) Stromgeschwindigkeiten und Strommengen in den Tiefen des Atlantischen Ozeans. Wissenschaftliche Ergebnisse der deutschen Atlantischen Expedition Forschungs- und Vermessungsschiff Meteor 1925-1927, 6, Teil 2, 6. Lieferung, 261-420. 